\title{
Correction to: Temperature Effects on Failure of Rotating Beam of Hybrid Composite
}

\author{
Getahun Aklilu • Glen Bright • Sarp Adali
}

Published online: 17 September 2020

(C) ASM International 2020

\section{Correction to: J Fail. Anal. and Preven.} https://doi.org/10.1007/s11668-020-00953-3

The article "Temperature Effects on Failure of Rotating Beam of Hybrid Composite", written by Getahun Aklilu et al., was originally published electronically on the publisher's internet portal (currently SpringerLink) on August 10, 2020, with open access. With the authors' decision to step back from Open Choice, the copyright of the article changed on September 9, 2020, to (C) ASM International 2020 and the article is forthwith distributed under the terms of copyright. The original article has been revised.

Publisher's Note Springer Nature remains neutral with regard to jurisdictional claims in published maps and institutional affiliations

The original article can be found online at https://doi.org/10.1007/ s11668-020-00953-3.

G. Aklilu $(\bowtie) \cdot$ G. Bright $\cdot$ S. Adali

Discipline of Mechanical Engineering, University of KwaZulu-

Natal, Durban, South Africa

e-mail: getmechanical@gmail.com

G. Bright

e-mail: brightg@ukzn.ac.za

S. Adali

e-mail: adali@ukzn.ac.za 